Article

\title{
Social Life Cycle Approach as a Tool for Promoting the Market Uptake of Bio-Based Products from a Consumer Perspective
}

\author{
Pasquale Marcello Falcone ${ }^{1, * \text { (i) } \text { and Enrica Imbert }}{ }^{2}$ \\ 1 Bioeconomy in Transition Research Group, IdEA, Unitelma Sapienza-University of Rome, \\ Viale Regina Elena, 291, 00161 Roma, Italy \\ 2 Department of Law and Economics, Unitelma-Sapienza University of Rome, Viale Regina Elena, 295, \\ 00161 Roma, Italy; enrica.imbert@unitelma.it \\ * Correspondence: pm.falcone@bioeconomy-in-transition.eu
}

Received: 23 February 2018; Accepted: 27 March 2018; Published: 30 March 2018

\begin{abstract}
The sustainability of bio-based products, especially when compared with fossil based products, must be assured. The life cycle approach has proven to be a promising way to analyze the social, economic and environmental impacts of bio-based products along the whole value chain. Until now, however, the social aspects have been under-investigated in comparison to environmental and economic aspects. In this context, the present paper aims to identify the main social impact categories and indicators that should be included in a social sustainability assessment of bio-based products, with a focus on the consumers' category. To identify which social categories and indicators are most relevant, we carry out a literature review on existing social life cycle studies; this is followed by a focus group with industrial experts and academics. Afterwards, we conduct semi-structured interviews with some consumer representatives to understand which social indicators pertaining to consumers are perceived as relevant. Our findings highlight the necessity for the development and dissemination of improved frameworks capable of exploiting the consumers' role in the ongoing process of market uptake of bio-based products. More specifically, this need regards the effective inclusion of some social indicators (i.e., end users' health and safety, feedback mechanisms, transparency, and end-of-life responsibility) in the social life cycle assessment scheme for bio-based products. This would allow consumers, where properly communicated, to make more informed and aware purchasing choices, therefore having a flywheel effect on the market diffusion of a bio-based product.
\end{abstract}

Keywords: social life cycle assessment; bio-based products; social indicators; consumers; sustainability

\section{Introduction}

Social sustainability is an essential component of sustainable development, even though it has been largely under-investigated when compared to economic and environmental components [1]. This is particularly true when restricting the spectrum of the analysis to the bio-based economy [2]. The bio-based economy includes the production of renewable biological resources and the conversion of these resources, residues, by-products and side streams into value added products such as food, feed, bio-based products, services and bioenergy [3]. According to the European Standard (EN 16575:2014), bio-based products are wholly or partly derived from materials of biological origin, excluding materials embedded in geological formations and/or fossilized. These might include chemicals, lubricants, surfactants, enzymes, pharmaceuticals, cosmetics, food additives, etc.

Promoting the use of bio-based products can support the transition from a linear towards a circular economy, creating jobs and enhancing a more sustainable growth [4]. However, while some policy 
documents (e.g., [5,6]) have supported the production of renewable biological resources and their conversion into value added products and bio-energy, there are also concerns about sustainability [7]. With the aim of ensuring an effective transition towards sustainability, it is of paramount importance that apposite assessment methods exist and are employed to discern pros and cons of different sustainability options [8].

In this respect, life cycle sustainability assessment (LSCA) represents a valuable framework whose transdisciplinary nature clearly demonstrates the importance of integrating not only with economic models but also with ecological and social theories [9]. However, as emphasized by [10], unlike reputable methods for assessing environmental and economic performance with environmental life cycle assessment (ELCA) and life cycle costing (LCC), social life cycle assessment (SLCA) is still in the development phase, and therefore misses the necessary empirical experience [11]. This is due in part to the lack of standardized social indicators for social performance measurements. The development of general SLCA indicators could provide organizations with relevant information to better understand those social factors that might influence their development over time [12]. This, in turn, would support empirical experience and accordingly contribute to the development of standardized LCSA constructs [10]. Moreover, the use of social indicators can assist decision makers in providing a fit-for-purpose social sustainability scheme, including standards, labels and certifications, based on the product-related impacts on the wellbeing of different stakeholders' categories [13].

Apart from deeply analyzing the theoretical foundations of SLCA, some academics have asked for scientific developments in providing improved methods and case studies with regard to the choice of impact categories and related indicators (e.g., [14,15]). Nonetheless, there is still a restricted number of contributions aimed at reviewing which social sustainability aspects are most relevant to consider throughout the SLCA. However, Kühnen and Hahn [10] recently reviewed trends, coherences, inconsistencies, and gaps in research on SLCA indicators across industry sectors. They found only a few sectors receiving adequate empirical attention to draw cautious conclusions that often neglect relevant social issues; this is because they focus mainly on worker- and health-related indicators. Lastly, Martin et al. [8], by means of a systematic review of scientific life cycle studies on bio-based products and an open space workshop with experts from academia and industry, underlined a discrepancy between those indicators found to be relevant, and the indicators that are recurrently included in the studies.

In this article, we complement the recent interest in understanding what key sustainability impacts and related indicators should be considered for the development, production, and market uptake of bio-based products [8]. We do this by focusing on a specific stakeholder category, namely consumers. This could help fill the gap concerning the overall lack of attention of SLCA research to stakeholder categories other than workers (see [10]). In this vein, SLCA is also a valuable tool for positioning a product in the market and to guide consumer purchases (see [16]). This becomes even more relevant when considering public measures for bio-based products, such as public procurement policies, and where mechanisms for establishing a level playing field with fossil-based products have not yet been implemented [4]. Furthermore, even when demand-side measures have been undertaken, such as in Italy (see [17]), the negative consequences originating from a general lack of social acceptance among consumers represent an important warning to all bioeconomy stakeholders (See http:/ / news.bio-based.eu/the-fight-on-plastics-heats-up-in-the-eu/). Accordingly, focusing on consumers is of paramount importance for deepening our knowledge of the main social aspects that may influence future demand and thus the market uptake of bio-based products, which is currently still limited.

The scope of our analysis ranges from scientific publications and official published documents (e.g., conference proceedings and books), including some from fields other than SLCA, to the so-called "grey literature" (e.g., dissertations and reports). These mostly focus on studies concerning the current situation of the bio-based sector in Europe from 2010 to early 2018. Our intended audience includes academics, practitioners and consumer organizations, as well as decision makers who are looking for 
reliable evaluation tools to enhance the understanding of which social aspects are worth considering, together with the key phases of design, production, marketing and consumption of bio-based products from the perspective of circular bioeconomy.

The rest of the paper is organized as follows: Section 2 frames the social sustainability of bio-based products and presents the research questions. Section 3 describes the methodology. Section 4 , starting from SLCA studies applied to bio-based products, proposes a comprehensive list of social impact categories and indicators tailored to bio-based products; the section shows results relevant to the consumers' category. Section 5 contains a discussion of the results. Finally, Section 6 concludes and suggests further developments of the study.

\section{The Context of Analysis and Research Questions}

In recent years, the socio-economic sustainability of products and processes has gained greater global attention. With reference to the bioeconomy, the European Union (EU) highlighted that bio-based products have a strong socio-economic dimension that needs to be taken into consideration $[3,5]$. Along this line of reasoning, Fritsche and Iriarte [18] observed that, in the early phases of the development of the bioeconomy, there was a focus on environmental criteria. At present, however, the further expansion of bio-based products makes the inclusion of social and socio-economic criteria a key issue.

Various studies have identified a wide range of social and socio-economic impacts related to bio-based products at different levels (company, local, national and international). In particular, it has been clearly pointed out that for the assessment of social aspects of bio-based products, upstream processes in the agricultural sector have a high social risk potential [19]. Indeed, the production of biomass affects access to land and land use [18] and the price of feedstocks, with direct and indirect effects on food production and security (see $[20,21])$. Moreover, given that a great percentage of raw materials are produced in countries with lower human rights standards, working conditions in this phase must be carefully monitored (see [20]). Another crucial issue relates to the impact of bio-based products on health and safety (see [22,23]). In this respect, Álvarez-Chávez et al. [24] have focused on the health and safety impacts of bioplastics throughout their life cycle.

Among the varying impacts, the effects of bio-based products on employment and the creation of new jobs (for example, temporary in nature or not), in both rural and industrial areas, also gained particular attention (e.g., [25-28]). Moreover, the literature also calls to other types of impact. Examples include those related to gender issues (see [2,29]).

Overall, the transition towards a bio-based economy is expected to deliver social and socio-economic benefits in a broad spectrum of areas, spanning from health and safety to working conditions, employment and prosperity, access to material and non-material resources, food and energy security, and gender issues (see [2,29]). These areas have been intertwined with Europe 2020 objectives and UN sustainable development goals (SDGs) (see [30,31]). Therefore, measuring these potential social and socio-economic improvements is of utmost importance for ensuring the sustainability of bio-based products while at the same time promoting their market uptake. Accordingly, this paper will seek to answer the following research questions:

RQ1: Which are the main impact categories and social indicators that should be included in a social sustainability assessment of bio-based products that take into consideration the whole value chain, from a social life cycle perspective?

RQ2: Which of the impact categories and social indicators, identified as pertaining to the consumers' category, are most relevant and could therefore, if properly communicated, encourage greater market penetration of bio-based products?

\section{Methodology}

To follow our research aims, we carried out a two-step investigation by means of: 
(i) a literature review on existing social life cycle studies on bio-based products, accompanied by a focus group to identify and validate the main social indicators pertaining to the consumers' category; and

(ii) semi-structured interviews with bioeconomy experts to ascertain the most relevant social impact categories and indicators from the consumers' perspective.

In the first step of our methodological approach, we conducted an in-depth peer-reviewed literature review from scientific journals and official published documents (e.g., conference proceedings and books), including some from fields other than SLCA. This review was then complemented by information from the so-called "grey literature" (e.g., dissertations and reports), mostly focusing on studies concerning the current situation of the bio-based sector in Europe.

For the examination of environmental, economic and social aspects, the review was carried out by looking at two main academic databases of peer-reviewed literature, namely Scopus (www.scopus.com) and Web of Science (www.webofscience.com); these databases were used because of their wide-ranging coverage of English-language scientific journals in social sciences. To extend our research, in order to also consider studies and reports not published in academic journals, we employed the Google search engine. We carried out a broad keyword search to detect important documents available online at the beginning of 2018. In this respect, we paired some anchor keywords (i.e., bio*, soci*, and sustainab*) with other search strings (i.e., "life cycle", "supply chain", "indicators", and "impacts"). Additionally, by means of an iterative method of search and discussion between the two authors and other scholars belonging to the same research group, additional search words were used with the aim of focusing the analysis mainly on social aspects in the context of bio-based products: bio-based products, bio-based products life cycle, social assessment of bio-based products, social indicators of bio-based products. This exercise allowed us to select studies dealing with the social dimension of bio-based products.

Our literature review shows the presence of more than 1000 studies on LCAs, focusing at a cradle-to-grave level. With the aim of addressing our research aims, and after having screened article abstracts, we found more than 500 papers that were relevant for a social performance assessment of a product, and more than 100 concerning bio-based products. However, the number of SLCA contributions concerning bio-based products was much smaller and amounted to 18 studies, four of which are case studies applied to bio-based products. See more information in Table 1.

To identify the main social indicators and criteria related to consumers, we also conducted a focus group exercise on the sustainability assessment of bio-based products, under the Horizon 2020 funded project STAR-ProBio. The study consisted of a group of 10 purposely sampled participants from different European countries (i.e., state agencies, public procurement experts, standardization and certification organizations, businesses and business associations, NGOs, and academia). They were intentionally selected and invited by means of gate-keepers (i.e., project partners) who were able to recruit people who, although with different professional backgrounds, share knowledge and general expertise on the bio-based economy; this was done to ensure both homogeneity and heterogeneity in the group creation [32].

The second step of our approach was meant to corroborate the preliminary findings that emerged from the literature review and the focus group, concentrating on the consumer stakeholder category. In particular, building from key issues raised in the first two steps, we administered a follow up semi-structured questionnaire to three experts with long-term involvement and expertise in the context of consumers' behavior and attitudes. These representatives were selected from a range of different organizations: (1) a consumer association; (2) a partner of the EU project BIOWAYS, involved in public awareness of the potential benefits of bio-based products; and (3) a public research center involved with consumers' acceptance drivers related to bio-based products. The questionnaire was administrated by telephone and lasted approximately one hour. The interviewees were asked to validate and integrate the proposed list of impact categories and social indicators according to their perspectives and knowledge, and then to appraise them in accordance with a five-option Likert scale, 
by arguing the weight of each answer. This exercise enabled us to elicit the value tree of the impact categories, social indicators, and possible indicators for the consumers' category.

\section{Results}

\subsection{S-LCA Applied to Bio-Based Products}

The literature review identified 18 studies concerning the social life cycle assessment for bio-based products. Eleven articles were scientifically published in peer-reviewed journals related to social, environmental, and sustainability topics, and four were case studies performing SLCA on bio-based products. In addition, we found seven contributions on bio-based products pertaining to the so called "grey literature".

Overall, the discussion over the sustainability of bio-based products throughout their life cycle, especially biofuels, has until now focused primarily on environmental issues [33-35]. In recent years, however, social and socio-economic aspects have gained increasing attention and have progressively been included in all sustainability schemes for biofuels [36]. However, when it comes to other bio-based products, the situation still lags behind [37]. This is probably imputable to the fact that bio-based products involve longer and more complex value chains [38] that make the assessment of social and socio-economic impacts extremely challenging.

Nonetheless, it is worth mentioning that there are some examples making increasing efforts to investigate the social and socio-economic impacts of bio-based products within a life cycle perspective. The Global-Bio-Pact EU FP7-funded project proposed a set of indicators and criteria for assessing the socio-economic impacts of biomass production and numerous conversion chains, with the aim of demonstrating the opportunities and limitations of the inclusion of socio-economic criteria in a European/International certification scheme [39]. The selection process was based on:

- $\quad$ a review of the literature;

- screening of socio-economic criteria and indicators in existing certification and standards; and

- indicators for bioenergy sustainability developed by initiatives such as the Global Bioenergy Partnership [40].

The impacts are related to six major categories: (i) contribution to the local economy; (ii) working conditions and rights; (iii) health and safety; (iv) gender; (v) land rights and conflicts; and (vi) food security. Additionally, the H2020 BioSTEP project, which engaged with the screening of social and socio-economic dimensions of bio-based products and processes, has revealed several interesting insights, with specific reference to bio-based plastics, chemicals and lubricants. Specifically, the following aspects were identified as the most risky: (i) the competition for feedstock and potential contribution to food insecurity; (ii) limited understanding among consumers; (iii) limited public perception in the EU; and (iv) job creation [20].

When looking specifically at the use of SLCA, it is worth noting that there is a rapidly growing literature with a strong focus on biofuels (e.g., [36,41-43]). Furthermore, there are also several studies utilizing SLCA to assess the social sustainability of recycling [44], packaging systems [45], and new technological processes (e.g., [46,47]). Table 1 reports a selected list of exemplifying studies performing SLCA on bio-based products. Impact categories, social indicators and scale of the analysis are identified for each of these studies. As can be clearly seen, there are important indicators common to these studies, such as health and rights of workers and contribution to employment, while others such as community engagement are less frequently addressed. Moreover, these studies have often taken different approaches since, as mentioned above and unlike with ELCA, there is still not a standardized methodology for SLCA. 
Table 1. SLCA case studies on bio-based products.

\begin{tabular}{|c|c|c|c|c|c|}
\hline Study & Main Objectives & Followed Approach & Impact Categories & Social Indicators & Scale \\
\hline$[36]$ & $\begin{array}{l}\text { - Comparing potential social and socio-economic } \\
\text { impacts of four types of vehicle fuels: two } \\
\text { bio-based (biodiesel and bioethanol) and two } \\
\text { fossil-fuel (diesel and petrol) utilized in the EU, } \\
\text { especially in Northern Europe and Sweden } \\
\text { - Identifying potential social hotspots. }\end{array}$ & $\begin{array}{l}\text { Use of the Social } \\
\text { Hotspot Database, } \\
\text { focusing on mostly risky } \\
\text { aspects } \\
\text { (screening S-LCA) }\end{array}$ & $\begin{array}{l}\text { A. Human rights; } \\
\text { B. Labor; } \\
\text { C. Health and safety; } \\
\text { D. Community; } \\
\text { E. Governance }\end{array}$ & $\begin{array}{l}\text { A } \rightarrow \text { Indigenous rights; high conflicts; gender equity; human } \\
\text { health issues } \\
\text { B } \rightarrow \text { Child labor; forced labor; excessive working time; wage } \\
\text { assessment; poverty; migrant labor; freedom of association, etc. } \\
\text { Unemployment; labor laws } \\
\text { C } \rightarrow \text { Injuries and fatalities; toxics and hazards } \\
\text { D } \rightarrow \text { Hospital beds; drinking water; Sanitation; children out of school; } \\
\text { smallholder or conventional farms } \\
\text { E } \rightarrow \text { Legal systems; Corruption }\end{array}$ & $\begin{array}{l}\text { Generic level: } \\
\text { country and/or } \\
\text { sector level data of } \\
\text { fuels within the } \\
\text { EU, especially in } \\
\text { Northern Europe } \\
\text { and Sweden }\end{array}$ \\
\hline$[41]$ & $\begin{array}{l}\text { - Social and socio-economic impacts of palm oil } \\
\text { biodiesel in a province of Indonesia }\end{array}$ & $\begin{array}{l}\text { - Impact categories and } \\
\text { criteria grounded on } \\
\text { UNEP-SETAC (2009), } \\
\text { preliminary survey and } \\
\text { literature review } \\
\text { - Weighting of the } \\
\text { criteria through experts' } \\
\text { evaluation (by } \\
\text { questionnaire) to ensure } \\
\text { further applicability } \\
\text { to MCDA }\end{array}$ & $\begin{array}{l}\text { A. Human rights; } \\
\text { B. Working conditions; } \\
\text { C. Cultural heritage; } \\
\text { D. Socio-economic } \\
\text { repercussions; } \\
\text { E. Governance }\end{array}$ & $\begin{array}{l}\text { A } \rightarrow \text { Free from the employment of child labor; free from the } \\
\text { employment of forced labor; equal opportunities; free } \\
\text { from discrimination. } \\
\text { B } \rightarrow \text { Freedom of association and collective bargaining; fair salary; } \\
\text { Decent working hours; occupational health and safety; social benefit. } \\
\text { C } \rightarrow \text { Land acquisition, delocalization, migration; respect of cultural } \\
\text { heritage and local wisdom; respect of customary rights of indigenous } \\
\text { people; community engagement; safe and healthy living conditions; } \\
\text { access to material resources; access to non-material resources; } \\
\text { Transparency of social/environmental issues } \\
D \rightarrow \text { Contribution to local employment; contribution to economic } \\
\text { development; food security; horizontal conflict; transfer of } \\
\text { technology and knowledge } \\
\text { E } \rightarrow \text { Public commitments to sustainability; fair competition; free } \\
\text { from corruption }\end{array}$ & Regional level \\
\hline [42] & $\begin{array}{l}\text { - Pointing out the difference between } \\
\text { performances, effects and impacts in conducting } \\
\text { an SLCA } \\
\text { - investigating social impacts/effects performing } \\
\text { a scenario analysis on biodiesel, comparing } \\
\text { different raw materials, i.e., palm oil, forest } \\
\text { biomass and algae }\end{array}$ & $\begin{array}{l}\text { - Approach based on } \\
\text { Weidema (2006), E-LCA, } \\
\text { Kim and Hur (2009), } \\
\text { Hofstetter and Norris } \\
\text { (2003), Norris (2006) }\end{array}$ & $\begin{array}{l}\text { A. Health; } \\
\text { B. Well-being }\end{array}$ & $\begin{array}{l}\text { A } \rightarrow \text { Company level: Health of the population; health of workers; } \\
\text { health in foreign countries } \\
\text { Regional level: Health of workers in the region; health of the } \\
\text { population in the region; } \\
\text { State level: Health of the national population; occupational health } \\
\text { B } \rightarrow \text { Regional level: Well-being of the region's population (no } \\
\text { tool available); } \\
\text { State level: Welfare (e.g., changes in poverty) of national population } \\
\text { (no tool available); Welfare of foreign populations }\end{array}$ & $\begin{array}{l}\text { General company, } \\
\text { region, state level }\end{array}$ \\
\hline$[44]$ & $\begin{array}{l}\text { - Assessing the social impacts of three Peruvian } \\
\text { recycling systems }\end{array}$ & $\begin{array}{l}\text { - Impact categories and } \\
\text { subcategories grounded } \\
\text { on UNEP-SETAC (2009) } \\
\text { and context } \\
\text { specific topics; }\end{array}$ & $\begin{array}{l}\text { A. Human rights; } \\
\text { B. Working conditions; } \\
\text { C. Socioeconomic } \\
\text { repercussions }\end{array}$ & $\begin{array}{l}\text { A } \rightarrow \text { Child labor; discrimination; freedom for association and } \\
\text { collective bargaining } \\
\mathrm{B} \rightarrow \text { Working hours; minimum income; fair income; recognized } \\
\text { employment relationships and fulfilment of legal social benefits; } \\
\text { physical working conditions; psychological working conditions } \\
\mathrm{C} \rightarrow \text { Education }\end{array}$ & $\begin{array}{l}\text { General/regional } \\
\text { level }\end{array}$ \\
\hline
\end{tabular}


In this respect, the approach developed by the EU-FP7 funded project "Prospective Sustainability Assessment of Technologies" (PROSUITE) has recently attracted great interest among scholars involved in bio-based product sustainability assessment. It integrates the social assessment within a comprehensive framework that brings together the three dimensions of sustainability. By identifying five main impact categories: (1) human health; (2) social well-being; (3) prosperity; (4) natural environment; and (5) exhaustible resources, PROSUITE defined a set of indicators with the objective of minimizing potential overlapping. With reference to social well-being, and in line with [48], PROSUITE took four core aspects into consideration: (i) autonomy; (ii) safety, security and tranquillity; (iii) equality; and (iv) participation and influence. This work was subsequently taken up by [29] who suggested a general "modified systemic approach for a social sustainability impact assessment", tailored to the bio-based economy. In particular, the authors paid particular attention to the second step of the SLCA, i.e., the inventory analysis. Within this step, the developed approach emphasized the importance of identifying, through the involvement of experts, the impact of (sub-)categories and indicators associated with the stakeholders' categories. Indeed, the identification of criteria for selecting these categories and indicators has been recognized as one of the most critical issues in conducting an SLCA (see, among others, [44]), which is also influenced by different perspectives and local contexts [49]. Taking this into account, the main indicators must also be selected and/or validated by the stakeholders (see [36]). Moreover, with reference to context-specific SLCA, various scholars [50,51] suggest the integration of top-down, universally recognized social sustainability aspects with bottom-up context-specific social aspects (for example, drawing on national and regional sustainability strategies, sector-specific issues and stakeholders' interests). In this vein, Mattila et al. [52] suggested an approach based on the integration of global methods with participatory methods involving local stakeholders.

In recent years, great efforts have been also made by the European Committee for Standardization (CEN) in defining social sustainability of bio-based products, in particular by the CEN technical committee for bio-based products (CEN/TC 411). When setting social criteria for the bio-based part of bio-based products (excluding food, feed and energy), EN 16751:2016 focused on:

(1) labor rights (including indicators on bargaining rights, elimination of forced labor, child labor and discrimination, safe working conditions for employees, knowledge required and training, living conditions, and satisfaction of the basic needs of employees);

(2) land use rights and land use change (including indicators related to respect for land use rights and on food security);

(3) water use rights in areas with water scarcity (including indicators on the identification of potential negative impacts related to water resources and measures to address them); and

(4) local development (description of measures undertaken to address local development).

It is worth noting, however, that access to data on bio-based products represents a major challenge. In this context, the Social Hotspot Database (SHDB), developed by Benoit-Norris et al. [53], represents a reference point for SLCA practitioners. However, as Ekener-Petersen et al. [36] pointed out, this database provides data at the sector level but not on specific sites/plants and products. This limitation makes it possible to identify only potential impacts (i.e., the identification of aspects where there are significant risks of social impact) but not actual impacts. Currently, another database on "Product Social Impact Life-Cycle Assessment" (PSILCA) has been developed by the sustainability consulting and software company GreenDelta. This database covers 88 indicators in total, addressing 25 main indicators (sub-categories). However, as emphasized by Rafiaani et al. [29], there are no specific data for bio-based products.

\subsection{List of Social Impact Categories and Indicators Tailored to Bio-Based Products}

At the end of this extensive review of social sustainability with a specific focus on bio-based products, a list of social impact categories and associated indicators can now be proposed (see Appendix A). This list is built on a set of frameworks that have already been applied by the 
literature. These are the BioSTEP project [20], the UNEP-SETAC guidelines and methodological sheets [54,55], the PROSUITE approach [46], the Global-Bio-Pact project [39], and the Global Bioenergy Partnership (GBEP) [40].

The list is composed of eight impact categories (see Figure 1), identified as relevant to bio-based products, i.e., health and safety, social acceptability, food security, employment, income, human rights and working conditions, gender issues and discrimination, and access to material resources and land use change.

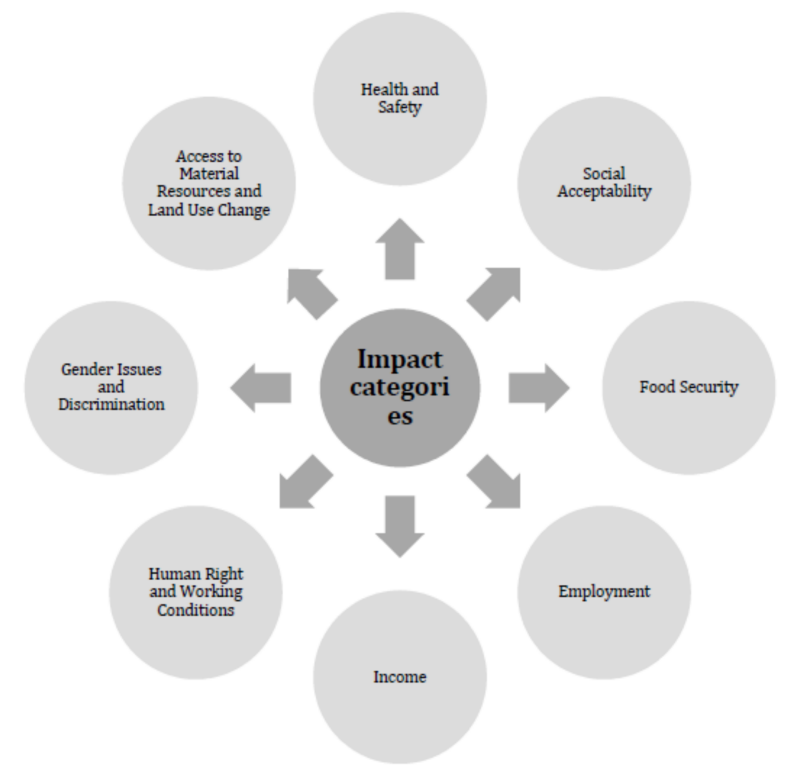

Figure 1. Impact categories tailored to bio-based products. Source: own elaboration.

Each impact category is related to different potentially affected categories of stakeholders [54], i.e., workers, consumers, local community, value chain actors and society. Consequently, each stakeholder category connected to different impact categories can, in turn, be associated to a wide range of indicators (Figure 2).

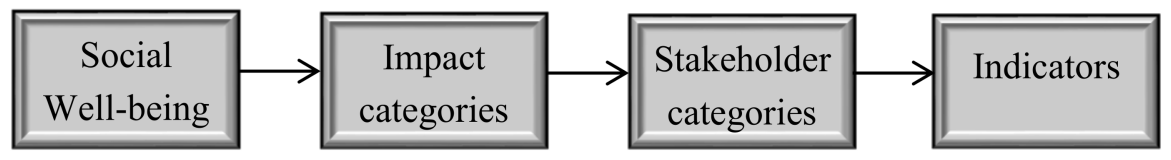

Figure 2. General framework for S-LCA tailored for bio-based products. Source: adapted from [54].

\subsection{Focus Group Exercise}

During the focus group, the experts were asked to identify the key sustainability criteria to be included in a sustainability assessment scheme for bio-based products. With reference to social categories and indicators to be included in an overall assessment, several issues were brought into discussion. First, it was outlined that, although environmental criteria are more evident for consumers, socio-economic criteria should also be considered. More specifically, it was pointed out that, even though the obligatory inclusion of social criteria for industry might be perceived as an obstacle to the creation of a level playing field with fossil-based products, it has also been stressed that properly communicating social impacts might be a key factor for increasing consumers' demand for bio-based products.

Another interesting point that came from the discussion relates to environmental criteria, i.e., the bio-based content of products. This content is strongly interlinked with one of the impact categories identified in the previous section, i.e., consumers' social acceptability. Specifically, it was stressed that a 
product that is not $100 \%$ bio-based may destabilize the consumer, not only for its potential detrimental effect on the environment but also for social reasons, in particular for possible negative health impacts. However, this is an issue that remains open since many products are not $100 \%$ bio-based; it has been emphasized that this represents a critical issue for consumers' social acceptability. The relevance of both social acceptability and health and safety for consumers, is in line with some preliminary results of a survey carried out in the framework of an $\mathrm{H} 2020$ project in which one of the focus group participants was involved.

The discussion then moved to consumers' perception towards bio-based products. Particularly, as clearly emerged, there is still no clear understanding of the bio-based idea, whose meaning might often be confused with "organic", "biodegradable" and "compostable" ideas. However, it has been stressed that consumers are usually aware that they would pay a higher price for bio-based products, and, therefore, their willingness to pay for such products must be supported by adequate information, including social criteria.

\subsection{Validation of Social Impact Categories and Indicators Related to Consumers}

To elicit consumers' perspectives about the most significant social impact categories and indicators to be included in the SLCA of bio-based products, we performed semi-structured interviews with experts. The interviews were carried out by telephone in February 2018, following an ice-breaking approach. More specifically, after clarifying our research goals, the respondents were asked to express their personal views about the role of consumers in defining the most relevant factors to enhance the market uptake of bio-based products. This was the opening question and enabled us to involve the respondents in the topic under investigation. We then illustrated our selected impact categories and social indicators (see Figure 3) in order to check their relevance (i.e., validation) for the consumers and, thus, to ascertain whether our experts believed they must be included in the social assessment of bio-based products related to this specific stakeholder category. Subsequently, they were asked to explore the possible integration of such social aspects.

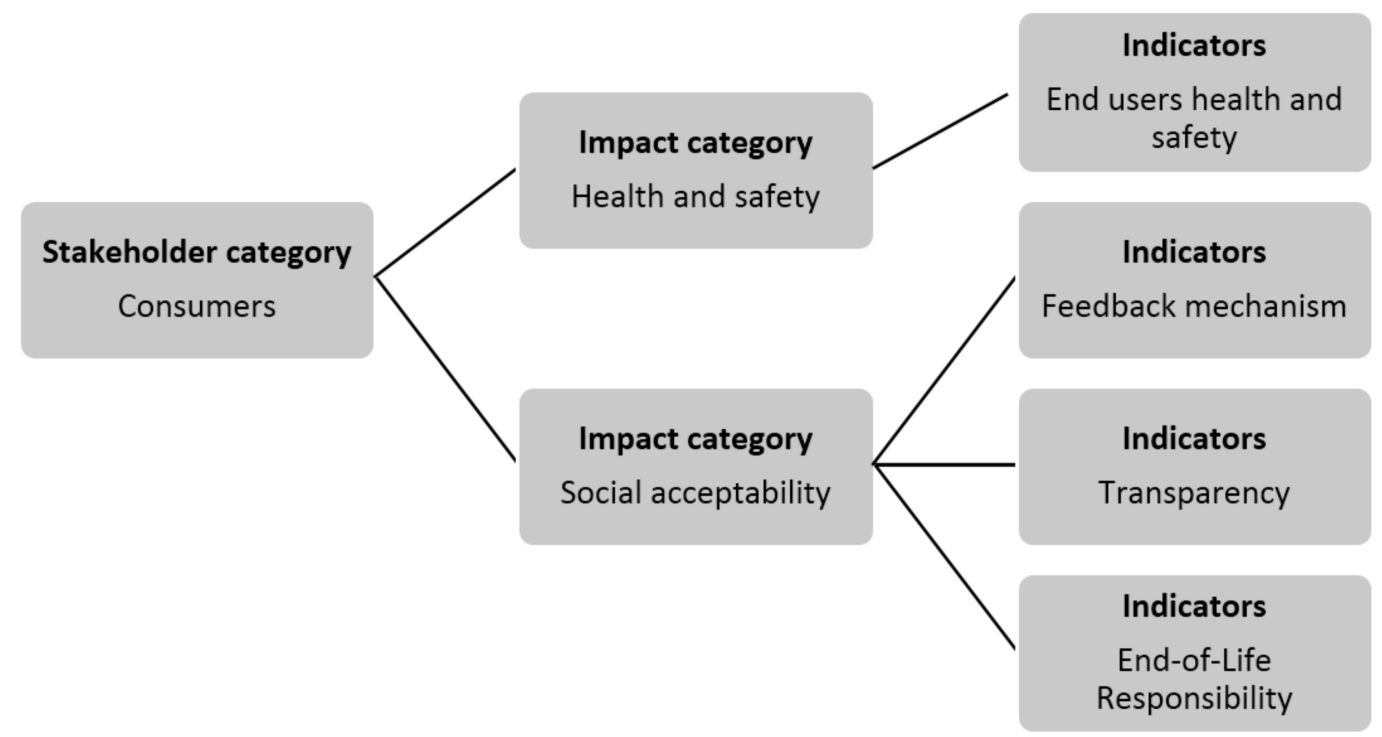

Figure 3. Value tree of the social impact categories and indicators for consumers' category. Source: own elaboration.

Overall, the respondents found the identified impact categories and social indicators relevant in the assessment of social sustainability of bio-based products, since they adequately describe the social aspects that characterize the investigated context. In particular, each question was assessed according to a five-option Likert scale (from $-2=$ not important to 2 = very important) to measure their relevance and to allow any possible neutral answers on an odd-numbered scale (see Figure 4). 


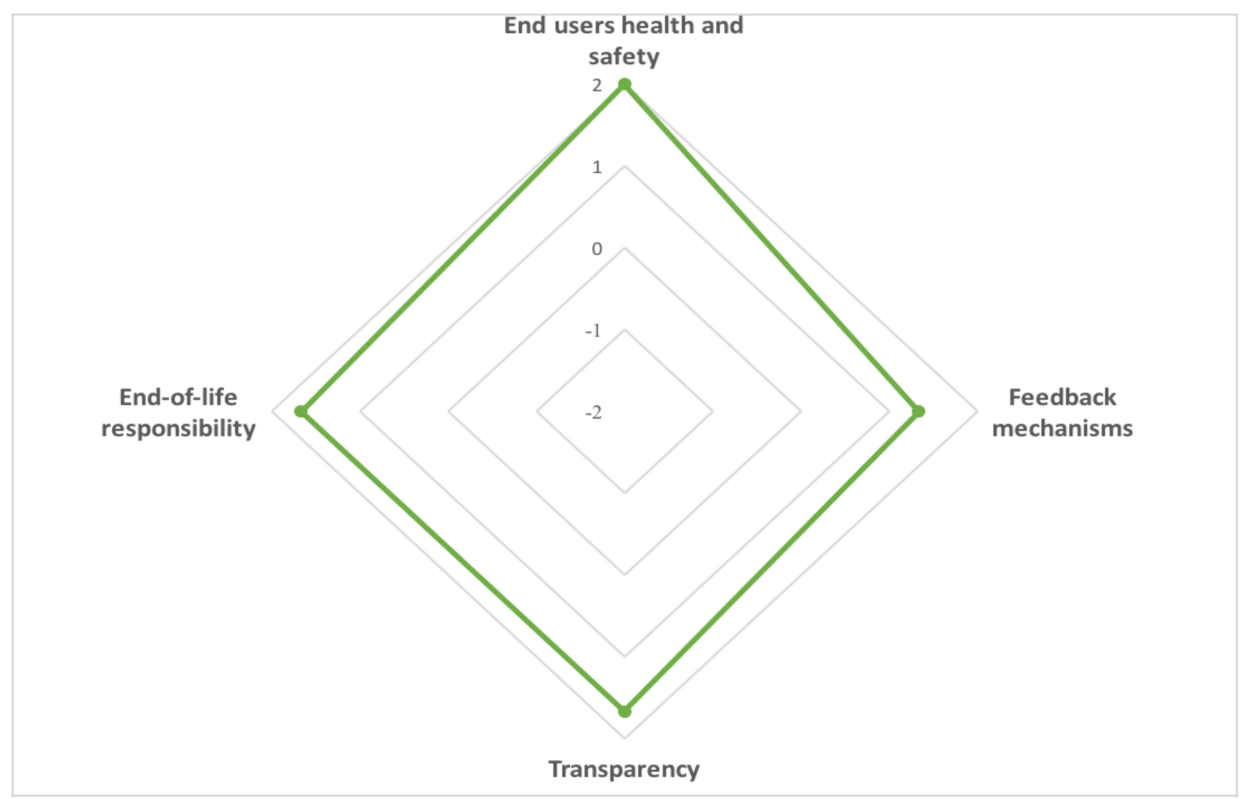

Figure 4. Five-option Likert scale for social indicators. Source: own elaboration.

All respondents recognized the health and safety impact category as "very important" since it is considered to be a key determinant for consumers. In particular, they emphasized that consumers' willingness to pay is strongly affected by this category. In line with the findings that emerged from the focus group, this has been outlined as a crucial factor for justifying the additional price that consumers are willing to pay for a product just for the fact that it is commonly understood as "eco-friendly" or, as for our case, "bio-based" (i.e., green premium). (In the framework of the European project BIOFOREVER (www.bioforever.org), nova-Institute is conducting a number of surveys on GreenPremium prices for bio-based products.) Moreover, one respondent stressed the importance of considering health and safety as separate impact categories since they explicitly reflect two different social themes. The social item found to be relevant for the Health and Safety impact category from the literature review, i.e., end-users health and safety, was ranked as "very important" by all respondents.

The second impact category, i.e., social acceptability, was found to be relevant by all respondents. In particular, two out of three recognized it as "very important" for the social assessment of bio-based products. Consumer social acceptability is driven by some specific social indicators that are worth taking into account, namely, feedback mechanisms, transparency and end-of-life responsibility. The presence of feedback mechanisms was found to be "important" for two respondents, and "very important" for the other. This highlights the significant role of feedback for consumers since they represent paths to communicate and signal their (dis)satisfaction to the organization in the use of bio-products. Moreover, as discovered by the interviews, those consumers oriented towards bio-based products often share a specific pro-environmental and social attitude that reflects their sensibility towards current concerns (i.e., climate change, depletion of resources, working conditions, quality of life, etc.); they wish to share these concerns with companies to gain more information on the products.

With reference to transparency, two respondents acknowledged this as "very important", while the third defined it as "important". In this vein, the presence of clear sustainability reports, labels and certification highlighting the (over)compliance with existing regulations, enable an informed choice for the consumer without intent to mislead or conceal. Moreover, according to respondents' opinions, the presence of strong transparency is another necessary condition to balance the higher prices of bio-based products compared to conventional ones with the same technical performance, as also already emphasized in the focus group exercise.

Finally, the end-of-life responsibility namely, the disposal, re-use or recycling of bio-based products, was rated by two respondents as "very important", highlighting the increasing diffusion among 
consumers of the circular economy concept. Conversely, according to an interviewee, the end-of-life responsibility social indicators, although recognized as "important", are a mere dimension on which consumers want to be informed for conscious recycling and disposal of the products.

\section{Discussion}

Following a general tendency of the literature, most of the studies on bio-based products entailing a life cycle perspective have focused on some fundamental themes recognized as crucial to be protected, i.e., human health, natural environment, natural resources, and man-made environment [56]. These have been defined as areas of protection (AoPs) and are addressed by the ELCA. However, as outlined by Reitinger et al. ([15], p. 381), "we are faced with the paradoxical situation of avoiding harm to environment and human health while ignoring other aspects of human life and thus the aims of sustainability". It was therefore suggested (i.e., [48,51]) that SLCA should complement the existing AoPs analyzed in ELCA by focusing on social well-being, which has been considered the primary AoP of LSCA [57]. Accordingly, the social impact assessment would involve impacts on the stakeholders' well-being that are associated with a wide range of indicators measuring the quality of life of people on both an individual and a collective level [46].

In this vein, the development of general SLCA indicators could provide organizations with relevant information to better understand those important social factors for positioning a product in the market and to guide consumer purchases (see [16]). It is worth noting that the use of biomass does not make bio-based products automatically sustainable or even, by definition, more sustainable than fossil-based products [58]. To this end, an SLCA therefore becomes crucial to compare "options, especially when complex supply chains are involved" [59]. In fact, for a market uptake of bio-based products, certain necessary conditions must be achieved, not only in terms of the implementation of appropriate policies (see, e.g., $[17,60]$ ) but also on the conditions that relate directly to consumer acceptability (see [61]).

As became apparent from the case studies considered in our review, and according to several scholars $[8,19]$, SLCA studies on bio-based products have focused mainly on social indicators relating to the worker stakeholder category while overlooking other stakeholders. Indeed, focusing on consumer perspectives is very important to deepen our knowledge on the main social sustainability indicators able to guarantee consumer well-being and therefore enhance the market development of bio-based products. In this regard, although it was stressed during the focus group exercise and expert interviews that consumers still have very little understanding of "bio-based" as a concept [62], they are at the same time aware of the higher pricing of bio-based products in comparison with more traditional products. In line with the literature (see $[61,63]$ ), we found that the willingness to pay represents a key factor. More specifically, the health and safety of consumers appears to be the factor that most influences the consumer's willingness to pay. In fact, moving towards the choice of bio-based products is also viewed as a change of consumer propensities. Far from dismissing the relevance of the health and safety impact category for both bio-based and traditional products, we observed that respondents emphasized that consumers expect bio-based products to perform their intended functions better, and to not pose risks to their health and safety. Therefore, as reported in Appendix A, both the presence of labels or standards (e.g., GRI 416) certifying an organization's systematic efforts to address health and safety along the life cycle of a product, and the organization's adherence to customer health and safety regulations, could have a flywheel effect on the market diffusion of a bio-based product. Furthermore, the analysis suggests that willingness to pay is also strongly related to social acceptability, whose lack represents a dramatic barrier (see [64]). This is in line with recent literature that proves that consumers, when confronted with eco-friendly purchase alternatives, respond not only rationally but also emotionally [65]; this could also be reflected in consumer acceptance of bio-based products [63]. Accordingly, the willingness to pay must be supported by adequate information, through certification, labels and development of standards for LCSA studies that are the core transparency (see Appendix A). Furthermore, the dynamic and active involvement of companies in providing user-friendly feedback 
mechanisms, in particular by means of social networks media, has been highlighted as a further catalyst for the market development of the bio-based products.

Finally, the end-of-life responsibility indicators also emerge as an important factor since, in several European countries, separate waste collection is mandatory or advocated. In this context, designing products in a smarter way, extending their useful lives, and providing complete and clear information for consumers regarding sustainable end-of-life options represent necessary changes for going well beyond the traditional resource efficiency and recycling of waste.

The discussion above clearly indicates the need for the development and dissemination of improved methods capable of exploiting the consumers' role in the ongoing process of market uptake of bio-based products. This need regards the effective inclusion of some social indicators (i.e., health and safety, and social acceptability, feedback mechanisms, strong transparency, and end-of-life responsibility) in the assessment scheme for bio-based products. This allows consumers, where properly communicated, to make more informed and aware purchasing choices.

\section{Conclusions and Recommendations for Further Analysis}

Together with environmental sustainability, demonstrating that bio-based products are also sustainable from a social and socio-economic perspective is critical to augment public acceptance and increase demand (see [66]). Overall, the proposed study provides an in-depth understanding of the impact categories and social indicators that should be included in an SLCA for bio-based products.

Our investigation allows the identification of a preliminary list of impact categories and social indicators grounded on an extensive literature review. Additionally, the focus group conducted under the Horizon 2020 funded project STAR-ProBio, and the interviews with experts, give us the opportunity to better explore and validate the impact categories and associated social indicators for consumers.

Several findings emerged from our investigation and can be synthetized as follows:

1. Eight impact categories have been identified as relevant for SLCA tailored to bio-based products. Moreover, a wide range of social indicators have been associated with different impact categories for potentially affected stakeholder categories.

2. Although the inclusion of social criteria in the assessment scheme for bio-based products might be perceived by the industry as an obstacle towards the creation of a level playing field with fossil-based products, if properly communicated, it might be a key factor for increasing consumer demand for bio-based products. Furthermore, as consumers are willing to pay a higher price for bio-based products, that willingness to pay should be supported by adequate information, including social life cycle impacts of the product.

3. The elicited experts' perspectives about the most significant consumer impact categories and social indicators to be included in the SLCA of bio-based products seem to endorse the findings that emerged from the literature review. In fact, both health and safety and social acceptability of consumers are perceived as very important impact categories on which to focus to achieve a comprehensive social assessment from the demand side. Moreover, the presence of adequate feedback mechanisms, strong transparency and end-of-life responsibility might allow consumers to make more informed and aware purchasing choices.

Our findings support evidence for going beyond the traditional life cycle assessment of products. From this perspective, SLCA provides the opportunity to accomplish a comprehensive social sustainability assessment in which all the involved parties (from industry to policy makers) should make an effort to tackle the proposed social indicators along the life cycle of the product. Its adherence to customer acceptance and health and safety could have a flywheel effect on the market diffusion of bio-based products.

The main limitation of this study rests on the restricted sample size of experts interviewed. However, it represents the first attempt in the literature to assess the relevance of social impact categories and social indicators from the perspective of consumers. Future empirical studies could 
apply our two-step methodology to other stakeholder categories, or other sectors that are relevant for transition towards sustainability.

Acknowledgments: The authors are very grateful to the STAR-ProBio project (Sustainability Transition Assessment and Research of Bio-based Products) for their financial support. The project is funded by the European Union's Horizon 2020 Research and Innovation Programme under Grant Agreement No. 727740, Work Programme BB-01-2016: Sustainability schemes for the bio-based economy.

Author Contributions: Both authors conceived and designed the study methodology and contributed to the primary share of the article writing. Enrica Imbert wrote the context of analysis and discussions sections. Pasquale Marcello Falcone wrote the introduction, methodology and conclusions. Both authors contributed to write results section.

Conflicts of Interest: The authors declare no conflict of interest.

\section{Appendix A}


Table A1. List of impact categories and social indicators suggested in the framework of SLCA within the bio-based economy.

\begin{tabular}{|c|c|c|c|}
\hline Impact Categories & Reference & Stakeholder Categories & Social Indicators \\
\hline \multirow{8}{*}{ Health and Safety } & BioSTEP (2016) & & $\begin{array}{l}\text { Health: } \\
\text { Exposure to agrochemicals; Numbers of multi-resistant organisms; Toxicity of "green" vs. "grey" industrial products }\end{array}$ \\
\hline & \multirow{3}{*}{$\begin{array}{l}\text { UNEP-SETAC } \\
(2009 ; 2013)\end{array}$} & Workers & $\begin{array}{l}\text { Health and safety: } \\
\text { Generic analysis (Hotspots): occupational accident rate by country: number/percentage of injuries or fatal accidents in the } \\
\text { organization by job qualification inside the company } \\
\text { Number of injuries per level of employees. Presence of a formal policy concerning health and safety. Adequate general } \\
\text { occupational safety measures are taken. Preventative measures and emergency protocols exist regarding accidents and } \\
\text { injuries. Preventative measures and emergency protocols exist regarding pesticide and chemical exposure. } \\
\text { Appropriate protective gear required in all applicable situations; number of serious/non-serious Occupational Safety and } \\
\text { Health Administration (OSHA) violations reported within the past three years and status of violations; education, training, } \\
\text { counseling, prevention and risk control programs in place to assist workforce members, their or community members } \\
\text { regarding serious diseases }\end{array}$ \\
\hline & & Consumers & $\begin{array}{l}\text { End-users health and safety: } \\
\text { Generic analysis (Hotspots): Quality of or number of information/signs on product health and safety; presence of consumer } \\
\text { complaints (at national, sectorial, organizational level); total number of incidents of non-compliance with regulations and } \\
\text { voluntary codes concerning health and safety impacts of products and services and type of outcomes (GRI PR2) } \\
\text { Specific analysis: Presence of labels on health and safety; number of consumer complaints; GRI 416 }\end{array}$ \\
\hline & & Local community & $\begin{array}{l}\text { Safe and healthy living conditions: } \\
\text { Generic analysis (Hotspots): Burden of Disease by Country; Pollution Levels by Country; Presence/Strength of Laws on } \\
\text { Construction Safety Regulations by Country } \\
\text { Specific Analysis: Management oversight of structural integrity; Organization's efforts to strengthen community health (e.g., } \\
\text { through shared community access to organization health resources); Management effort to minimize use of } \\
\text { hazardous substances }\end{array}$ \\
\hline & \multirow{2}{*}{ PROSUITE (2013) } & Occupational health & Number of: non-fatal accidents at work; fatal accidents at work; occupational diseases \\
\hline & & Environmental Human health & Climate change; ozone depletion; human toxicity; respiratory inorganics; ionizing radiation \\
\hline & $\begin{array}{l}\text { Global-Bio-Pact } \\
\quad(2012)\end{array}$ & Workers & $\begin{array}{l}\text { Work related accidents and diseases: Number of work related accidents per person days of employment per year, number of } \\
\text { work related diseases/person days of employment per year. Personal protective equipment: Percentage of workers that use } \\
\text { appropriate personal protective equipment. OSH training: Percentage of employees that have received OSH (Occupational } \\
\text { Safety and Health) training }\end{array}$ \\
\hline & GBEP (2011) & Not proposed & $\begin{array}{l}\text { Change in mortality and burden of disease attributable to indoor smoke. Incidence of occupational injury, illness } \\
\text { and fatalities }\end{array}$ \\
\hline
\end{tabular}


Table A1. Cont.

\begin{tabular}{|c|c|c|c|}
\hline Impact Categories & Reference & Stakeholder Categories & Social Indicators \\
\hline \multirow{15}{*}{ Social Acceptability } & \multirow{11}{*}{$\begin{array}{l}\text { UNEP-SETAC } \\
(2009 ; 2013)\end{array}$} & \multirow{7}{*}{ Consumers } & Feedback Mechanism: \\
\hline & & & Presence of a mechanism for customers to provide feedback. Management measures to improve feedback mechanisms. \\
\hline & & & Practices related to customer satisfaction, including results of surveys measuring customer satisfaction. \\
\hline & & & Transparency: \\
\hline & & & $\begin{array}{l}\text { Compliance with regulations regarding transparency; publication of a sustainability report; divulgence of results on ELCA } \\
\text { and SLCA; Number of certifications and labels }\end{array}$ \\
\hline & & & End-of-Life Responsibility: \\
\hline & & & $\begin{array}{l}\text { Presence of clear information provided to consumers on end-of-life; number of incidents of non-compliance with regulatory } \\
\text { labeling requirements }\end{array}$ \\
\hline & & \multirow[b]{2}{*}{ Value chain actors } & Promoting Social Responsibility: \\
\hline & & & $\begin{array}{l}\text { Presence of explicit code of conduct that protects human rights of workers among suppliers. Membership of an initiative } \\
\text { that promotes social responsibility along the supply chain }\end{array}$ \\
\hline & & \multirow[b]{2}{*}{ Society } & Public Commitment to Sustainability Issues: \\
\hline & & & $\begin{array}{l}\text { Presence of publicly available documents as promises or agreements on sustainability issues. Formalized commitment of the } \\
\text { organization to prevent corruption, referring to recognized standards. }\end{array}$ \\
\hline & \multirow{3}{*}{$\begin{array}{l}\text { Global-Bio-Pact } \\
\quad(2012)\end{array}$} & Workers & $\begin{array}{l}\text { Involvement of smallholders or small suppliers. Percentage of feedstock that originates from associates, smallholders, and } \\
\text { out-growers. }\end{array}$ \\
\hline & & \multirow[b]{2}{*}{ Local community } & Contribution to local economy: \\
\hline & & & $\begin{array}{l}\text { Amount invested in community investment projects (e.g., CSR) (percent of annual revenue) and qualitative description of } \\
\text { investments including any projects specific for women. }\end{array}$ \\
\hline & GBEP (2011) & Workers & $\begin{array}{l}\text { Training and requalification of workforce (i.e., share of trained workers in the bio-energy sector out of total bio-energy } \\
\text { workforce, and share of re-qualified workers out of the total number of jobs lost in the bio-energy sector) }\end{array}$ \\
\hline \multirow{5}{*}{ Food Security } & BioSTEP (2016) & Not proposed & $\begin{array}{l}\text { Use of agrochemicals (including fertilizers) and GMO crops; change in food prices (and its volatility); malnutrition, risk of } \\
\text { hunger; macronutrient intake/availability }\end{array}$ \\
\hline & \multirow{4}{*}{$\begin{array}{l}\text { Global-Bio-Pact } \\
\quad(2012)\end{array}$} & $\begin{array}{l}\text { Workers and Local } \\
\quad \text { community }\end{array}$ & $\begin{array}{l}\text { Availability of food: Perceived change in availability of food after the beginning of bio-energy operations } \\
\text { Time spent in subsistence agriculture: Change in time spent in subsistence agriculture in the household }\end{array}$ \\
\hline & & \multirow[b]{2}{*}{$\begin{array}{l}\text { Processing company or } \\
\text { plantation }\end{array}$} & Land that has been converted from staple crops (ha) \\
\hline & & & $\begin{array}{l}\text { Edible feedstock diverted from food chain to bio-energy: amount of edible raw material diverted into bio-energy } \\
\text { production }(\mathrm{t})\end{array}$ \\
\hline & & Government and NGOs & Land that has been converted from staple crops (ha) \\
\hline
\end{tabular}


Table A1. Cont.

\begin{tabular}{|c|c|c|c|}
\hline Impact Categories & Reference & Stakeholder Categories & Social Indicators \\
\hline & & & $\begin{array}{l}\text { Price and supply of a national food basket, allocation and tenure of land for new bio-energy production (percentage of land } \\
\text { used for new bio-energy production). Change in income (wages paid for employment into bio-energy sector in relation to } \\
\text { comparable sectors; net income from the sale, barter and/or own consumption of bio-energy products, including feedstocks, } \\
\text { by self-employed households/individuals) }\end{array}$ \\
\hline & GBEP (2011) & Not proposed & $\begin{array}{l}\text { Bio-energy used to expand access to modern energy services (total amount and percentage of increased access to modern } \\
\text { energy services gained through modern bio-energy, measured in terms of energy and numbers of households and businesses. } \\
\text { Jobs in the bio-energy sector as a result of bio-energy production and use (total number of jobs in the bio-energy sector and } \\
\text { percentage adhering to nationally recognized labor standards consistent with the principles enumerated in the ILO } \\
\text { Declaration on Fundamental Principles and Rights at Work, in relation to comparable sectors). }\end{array}$ \\
\hline \multirow{11}{*}{ Employment } & $\operatorname{BioSTEP}(2016)$ & Not proposed & Change in employment rate; full time equivalent jobs; job quality; need for/lack of highly specialized work force \\
\hline & \multirow{6}{*}{$\begin{array}{l}\text { UNEP-SETAC } \\
(2009 ; 2013)\end{array}$} & Local community & $\begin{array}{l}\text { Local employment: } \\
\text { Generic analysis (Hotspots): Unemployment and poverty statistics by region } \\
\text { Specific analysis: Percentage of workforce hired locally; Strength of policies on local hiring preferences; percentage of } \\
\text { spending on locally based suppliers }\end{array}$ \\
\hline & & \multirow[b]{3}{*}{ Workers } & Hours of works: \\
\hline & & & Generic analysis (Hotspots): excessive hours of work \\
\hline & & & $\begin{array}{l}\text { Specific analysis: Number of hours effectively worked by employees (at each level of employment); number of holidays } \\
\text { effectively used by employees; clear communication of working hours and overtime arrangements; respect of contractual } \\
\text { agreements concerning overtime }\end{array}$ \\
\hline & & \multirow[b]{2}{*}{ Society } & Contribution to economic development: \\
\hline & & & $\begin{array}{l}\text { Economic situation of the country/region (GDP, economic growth, unemployment, wage level, etc.); Relevance of the } \\
\text { considered sector for the (local) economy (share of GDP, number of employees in relation to size of working population, } \\
\text { wage level, etc.) }\end{array}$ \\
\hline & PROSUITE (2013) & Social wellbeing & Safety, security and tranquility (knowledge-intensive jobs, total employment) \\
\hline & \multirow{3}{*}{$\begin{array}{l}\text { Global-Bio-Pact } \\
\quad(2012)\end{array}$} & & Contribution to local economy: \\
\hline & & $\begin{array}{l}\text { Workers and processing } \\
\text { company }\end{array}$ & $\begin{array}{l}\text { Total number of employees and person days of employment per year. Number of workers that have received training (for } \\
\text { skills development, education, etc.) each year, number of working days spent in training provided by the operation each } \\
\text { year, type of training. }\end{array}$ \\
\hline & & $\begin{array}{l}\text { Government and Local } \\
\text { community }\end{array}$ & $\begin{array}{l}\text { Contribution to local economy: } \\
\text { Ratio of employment from local area/outside local area per category of employment. Percentage of workers that have a } \\
\text { fixed contract employment per category of employment }\end{array}$ \\
\hline \multirow{4}{*}{ Income } & $\operatorname{BioSTEP}(2016)$ & Households income & Income of employees in bio-economy sector (total); distribution of income \\
\hline & PROSUITE (2013) & Social wellbeing & Global Income Inequalities between GDP levels around the world. \\
\hline & \multirow{2}{*}{$\begin{array}{l}\text { Global-Bio-Pact } \\
\quad(2012)\end{array}$} & $\begin{array}{l}\text { Workers and processing } \\
\text { company }\end{array}$ & $\begin{array}{l}\text { Working conditions and rights: } \\
\text { Average income of employees by category of employment (EUR) }\end{array}$ \\
\hline & & Workers and local community & $\begin{array}{l}\text { Working conditions and rights: } \\
\text { Income spent on basic needs (percentage of worker's disposable income spent on fulfilling basic needs (food, } \\
\text { accommodation and transport) }\end{array}$ \\
\hline
\end{tabular}


Table A1. Cont.

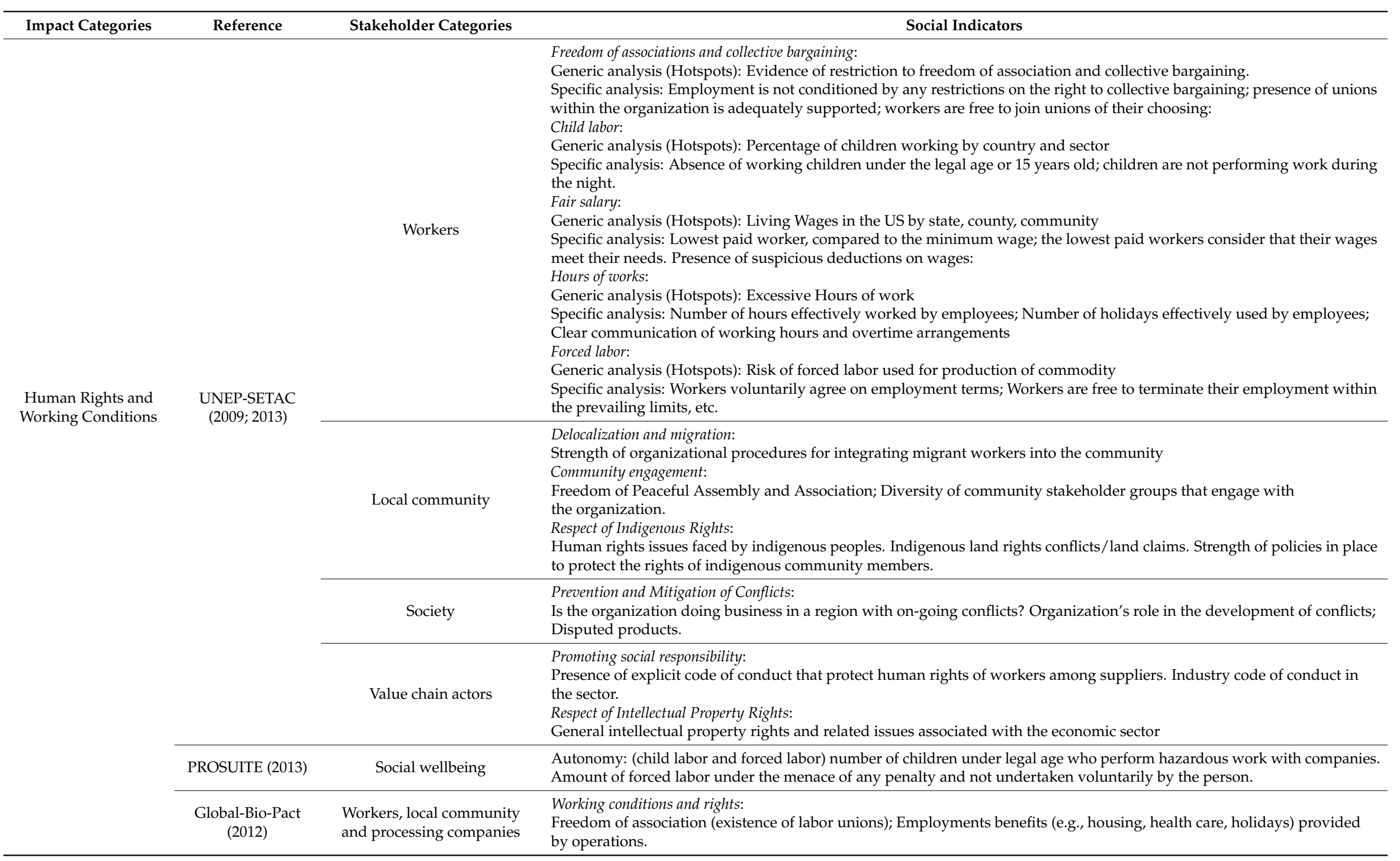


Table A1. Cont.

\begin{tabular}{|c|c|c|c|}
\hline Impact Categories & Reference & Stakeholder Categories & Social Indicators \\
\hline \multirow{5}{*}{$\begin{array}{l}\text { Gender Issues and } \\
\text { Discrimination }\end{array}$} & $\operatorname{BioSTEP}(2016)$ & Not proposed & Property rights; access to land; quality of life (equality of genders) \\
\hline & \multirow{2}{*}{$\begin{array}{l}\text { UNEP-SETAC } \\
(2009 ; 2013)\end{array}$} & Workers & $\begin{array}{l}\text { Equal opportunities/Discrimination: } \\
\text { Generic analysis (Hotspots): Women in the labor force participation rate by country; country gender index ranking } \\
\text { Specific analysis: Presence of formal policies on equal opportunities; total numbers of incidents of discrimination and actions } \\
\text { taken; ratio of basic salary of men to women by employee category }\end{array}$ \\
\hline & & Value chain actors & $\begin{array}{l}\text { Promoting Social Responsibility: } \\
\text { Integration of ethical, social, environmental and regarding gender equality in purchasing policy, distribution policy and } \\
\text { contract signatures }\end{array}$ \\
\hline & \multirow{2}{*}{$\begin{array}{l}\text { Global-Bio-Pact } \\
\quad(2012)\end{array}$} & $\begin{array}{l}\text { Workers and processing } \\
\text { companies }\end{array}$ & $\begin{array}{l}\text { Gender: } \\
\text { Benefits created for woman (i.e., maternity leave, and others) }\end{array}$ \\
\hline & & $\begin{array}{l}\text { Community and processing } \\
\text { companies }\end{array}$ & $\begin{array}{l}\text { Contribution to local economy: } \\
\text { Investments in projects (percent of annual revenue) including any programs specific for women }\end{array}$ \\
\hline \multirow{6}{*}{$\begin{array}{l}\text { Access To Material } \\
\text { Resources and Land } \\
\text { Use Change }\end{array}$} & BioSTEP (2016) & Land access & Land prices, Land tenure, Property rights, Access to land. \\
\hline & $\begin{array}{l}\text { UNEP-SETAC } \\
(2009 ; 2013)\end{array}$ & Local community & $\begin{array}{l}\text { Access to Material Resources: } \\
\text { Generic analysis (Hotspots): Changes in land ownership. Levels of industrial water use. Extraction of material resources. } \\
\text { Percentage of population (urban, rural, total) with access to improved sanitation facilities. } \\
\text { Specific Analysis: Has the organization developed a project related infrastructure with mutual community access and } \\
\text { benefit? Strength of organizational risk assessment with regard to potential for material resource conflict. Does the } \\
\text { organization have a certified environmental management system? }\end{array}$ \\
\hline & PROSUITE (2013) & Not proposed & Water use, terrestrial; Land use \\
\hline & \multirow{2}{*}{$\begin{array}{l}\text { Global-Bio-Pact } \\
\quad(2012)\end{array}$} & Processing companies & $\begin{array}{l}\text { Land rights and conflicts: } \\
\text { Legal title of land right-has a legal title/concession for the land that is not challenged? } \\
\text { Communal/ public land and land conflicts-has the operation had any land use conflicts, if so, what caused them, how were } \\
\text { they resolved? }\end{array}$ \\
\hline & & Government and NGOs & $\begin{array}{l}\text { Land rights and conflicts: } \\
\text { Legal title of land right-operation has a legal title/concession for the land that is not challenged. Area of land currently } \\
\text { under dispute, land conflict. Has the operation had any land use conflicts, if so, what caused them, how were they resolved? }\end{array}$ \\
\hline & GBEP (2011) & Not proposed & $\begin{array}{l}\text { Access to land, water and other natural resources: } \\
\text { Allocation and tenure of land for new bio-energy production }\end{array}$ \\
\hline
\end{tabular}




\section{References}

1. Hutchins, M.J.; Sutherland, J.W. An exploration of measures of social sustainability and their application to supply chain decisions. J. Clean. Prod. 2008, 16, 1688-1698. [CrossRef]

2. Sillanpää, M.; Ncibi, C. A Sustainable Bioeconomy: The Green Industrial Revolution; Springer: Cham, Switzerland, 2017.

3. European Commission. Bio-Based Economy in Europe: State of Play and Future Potential-Part 2 Summary of Position Papers Received in Response to the European Commission's public On-line Consultation, 2011. Available online: https:/ / ec.europa.eu/research/consultations/bioeconomy/bio-based-economyfor-europe-part2.pdf (accessed on 9 January 2018).

4. EuropaBio. Building a Bio-Based Economy for Europe for 2020, EuropaBio Policy Guide. 2011. Available online: http:/ / www.europabio.org/industrial-biotech/publications/building-bio-based-economy-europe2020 (accessed on 9 January 2018).

5. European Commission. Innovating for Sustainable Growth-A Bioeconomy for Europe; European Commission, Directorate Research and Innovation: Brussels, Belgium, 2012.

6. EuropaBio, 2011, Bioeconomy from a Vision to a Realty. Available online: https://www.europabio.org/ sites/default/files/bieconomy_-_from_vision_to_reality.pdf (accessed on 9 January 2018).

7. Falcone, P.M.; Lopolito, A.; Sica, E. Policy mixes towards sustainability transition in the Italian biofuel sector: Dealing with alternative crisis scenarios. Energy Res. Soc. Sci. 2017, 33, 105-114. [CrossRef]

8. Martin, M.; Røyne, F.; Ekvall, T. Moberg, Å. Life Cycle Sustainability Evaluations of Bio-based Value Chains: Reviewing the indicators from a Swedish Perspective. Sustainability 2018, 10, 547. [CrossRef]

9. Zamagni, A. Life cycle sustainability assessment. Int. J. Life Cycle Assess. 2012, 17, 373-376. [CrossRef]

10. Kühnen, M.; Hahn, R. Indicators in Social Life Cycle Assessment-A Review of Frameworks, Theories, and Empirical Experience. J. Ind. Ecol. 2017, 21, 1547-1565. [CrossRef]

11. Baumann, H.; Arvidsson, R.; Tong, H.; Wang, Y. Does the production of an airbag injure more people than the airbag saves in traffic? J. Ind. Ecol. 2013, 17, 517-527. [CrossRef]

12. Lamberton, G. Sustainability accounting: A brief history and conceptual framework. Account. Forum 2005, 29, 7-26. [CrossRef]

13. Jørgensen, A.; Dreyer, L.C.; Wangel, A. Addressing the effect of social life cycle assessment. Int. J. Life Cycle Assess. 2012, 17, 828-839. [CrossRef]

14. Mathe, S. Integrating participatory approaches into social life cycle assessment: The SLCA participatory approach. Int. J. Life Cycle Assess. 2014, 19, 1506-1514. [CrossRef]

15. Reitinger, C.; Dumke, M.; Barosevcic, M.; Hillerbrand, R. A conceptual framework for impact assessment within SLCA. Int. J. Life Cycle Assess. 2011, 16, 380-388. [CrossRef]

16. Parent, J.; Cucuzzella, C.; Revéret, J.P. Revisiting the role of LCA and SLCA in the transition towards sustainable production and consumption. Int. J. Life Cycle Assess. 2013, 18, 1642-1652. [CrossRef]

17. Imbert, E.; Ladu, L.; Morone, P.; Quitzow, R. Comparing policy strategies for a transition to a bioeconomy in Europe: The case of Italy and Germany. Energy Res. Soc. Sci. 2017, 33, 70-81. [CrossRef]

18. Fritsche, U.R.; Iriarte, L. Sustainability criteria and indicators for the bio-based economy in Europe: State of discussion and way forward. Energies 2014, 7, 6825-6836. [CrossRef]

19. Spierling, S.; Knüpffer, E.; Behnsen, H.; Mudersbach, M.; Krieg, H.; Springer, S.; Albrecht, S.; Herrmann, C.; Endres, H.J. Bio-based plastics-A review of environmental, social and economic impact assessments. J. Clean. Prod. 2018. [CrossRef]

20. Hasenheit, M.; Gerdes, H.; Kiresiewa, Z.; Beekman, V. Summary Report on the Social, Economic and Environmental Impacts of the Bioeconomy, BioSTEP. 2016. Available online: http://www.bio-step.eu/ results.html (accessed on 8 September 2017).

21. Kline, K.L.; Msangi, S.; Dale, V.H.; Woods, J.; Souza, G.M.; Osseweijer, P.; Clancy, J.S.; Hilbert, J.A.; Johnson, F.X.; McDonnell, P.C.; et al. Reconciling food security and bioenergy: Priorities for action. GCB Bioenergy 2017, 9, 557-576. [CrossRef]

22. BIOCHEM Project D2.3 Report on the Assessment of the Bio-Based Products Market Potential for Innovation. Available online: http:/ / www.biochem-project.eu/download/toolbox/innovation/06/Biobased\%20product\%20market\%20potential.pdf (accessed on 6 September 2017).

23. Massawe, E.; Geiser, K.; Ellenbecker, M.; Marshall, J. Health, safety, and ecological implications of using biobased floor-stripping products. J. Environ. Health 2007, 69, 45. [PubMed] 
24. Álvarez-Chávez, C.R.; Edwards, S.; Moure-Eraso, R.; Geiser, K. Sustainability of bio-based plastics: General comparative analysis and recommendations for improvement. J. Clean. Prod. 2012, 23, 47-56. [CrossRef]

25. OECD. Bio-Based Chemicals and Bioplastics: Finding the Right Policy Balance; OECD Science, Technology and Industry Policy Papers, No. 17; OECD Publishing: Paris, France, 2014.

26. Ronzon, T.; Santini, F.; M'Barek, R. The Bioeconomy in the European Union in Numbers. Facts and Figures on Biomass, Turnover and Employment; European Commission, Joint Research Centre, Institute for Prospective Technological Studies: Seville, Spain, 2015; p. 4.

27. Reinshagen, P. Bioeconomy: Much More Employment in Bio-Based Chemicals Than in Biofuels; Bio Based Press: Amsterdam, The Netherlands, 2015; Available online: http://www.bio-basedpress.eu/ 2015/06/bioeconomy-much-moreemployment-in-bio-based-chemicals-than-in-biofuels / (accessed on 10 January 2018).

28. Piotrowski, S.; Carus, M.; Carrez, D. European Bioeconomy in Figures. 2016. Available online: http:// biconsortium.eu/sites/biconsortium.eu/files/downloads/20160302_Bioeconomy_in_figures.pdf (accessed on 18 September 2017).

29. Rafiaani, P.; Kuppens, T.; Van Dael, M.; Azadi, H.; Lebailly, P.; Van Passel, S. Social sustainability assessments in the bio-based economy: Towards a systemic approach. Renew. Sustain. Energy Rev. 2018, 82, 1839-1853. [CrossRef]

30. Anand, M. Innovation and Sustainable Development: A Bioeconomic Perspective; Brief for Global Sustainable Development Report 2016. Available online: https:/ / sustainabledevelopment.un.org/content/ documents/982044_Anand_Innovation\%20and\%20Sustainable\%20Development_A\%20Bioeconomic\% 20Perspective.pdf (accessed on 10 January 2018).

31. German Bioeconomy Counsil, Nature commentary: Bioeconomy important for SDGs, 2016. Available online: http:/ / biooekonomierat.de/en/news/the-bioeconomy-is-central-to-the-achievement-of-climateprotection-and-sdgs / (accessed on 10 January 2018).

32. Morgan, D.L. Focus Groups as Qualitative Research, 2nd ed.; SAGE Publications: Thousand Oaks, CA, USA, 1997.

33. Pawelzik, P.; Carus, M.; Hotchkiss, J.; Narayan, R.; Selke, S.; Wellisch, M.; Weiss, M.; Wicke, B.; Patel, M.K. Critical aspects in the life cycle assessment (LCA) of bio-based materials-Reviewing methodologies and deriving recommendations. Res. Conserv. Recycl. 2013, 73, 211-228. [CrossRef]

34. Hottle, T.A.; Bilec, M.M.; Landis, A.E. Sustainability assessments of bio-based polymers. Polym. Degrad. Stab. 2013, 98, 1898-1907. [CrossRef]

35. Tsiropoulos, I.; Faaij, A.P.; Lundquist, L.; Schenker, U.; Briois, J.F.; Patel, M.K. Life cycle impact assessment of bio-based plastics from sugarcane ethanol. J. Clean. Prod. 2015, 90, 114-127. [CrossRef]

36. Ekener-Petersen, E.; Höglund, J.; Finnveden, G. Screening potential social impacts of fossil fuels and biofuels for vehicles. Energy Policy 2014, 73, 416-426. [CrossRef]

37. Rutz, D.; Janssen, R. Summary Report of the Global-Bio-Pact Project, Global Assessment of Biomass and Bioproduct Impacts on Socio-Economics and Sustainability. 2013. Available online: http://www. globalbiopact.eu/ (accessed on 5 September 2017).

38. Bell, G.; Schuck, S.; Jungmeier, G.; Wellisch, M.; Felby, C.; Jørgensen, H.; Spaeth, J. IEA Bioenergy Task42 Biorefining; IEA Bioenergy: Wageningen, The Netherlands, 2014.

39. Diaz-Chavez, R.; Rettenmaier, N.; Rutz, D.; Janssen, R. Global-Bio-Pact Set of Selected Socio-Economic Sustainability Criteria and Indicators, Imperial College; Report of the FP7 Global-Bio-Pact Project. 2012. Available online: http://www.globalbiopact.eu/socio-economic-impacts.html (accessed on 4 September 2017).

40. FAO. The Global Bioenergy Partnership (GBEP) Sustainability Indicators for Bioenergy, 1st ed.; GBEP Secretariat e FAO: Rome, Italy, 2011; 223p, Available online: http://www.globalbioenergy.org/fileadmin/user_ upload/gbep/docs/Indicators/The_GBEP_Sustainability_Indicators_for_Bioenergy_FINAL.pdf (accessed on 4 September 2017).

41. Manik, Y.; Leahy, J.; Halog, A. Social life cycle assessment of palm oil biodiesel: A case study in Jambi Province of Indonesia. Int. J. Life Cycle Assess. 2013, 18, 1386-1392. [CrossRef]

42. Macombe, C.; Leskinen, P.; Feschet, P.; Antikainen, R. Social life cycle assessment of biodiesel production at three levels: A literature review and development needs. J. Clean. Prod. 2013, 52, 205-216. [CrossRef] 
43. Raman, S.; Mohr, A.; Helliwell, R.; Ribeiro, B.; Shortall, O.; Smith, R.; Millar, K. Integrating social and value dimensions into sustainability assessment of lignocellulosic biofuels. Biomass Bioenergy 2015, 82, 49-62. [CrossRef] [PubMed]

44. Aparcana, S.; Salhofer, S. Application of a methodology for the social life cycle assessment of recycling systems in low income countries: Three Peruvian case studies. Int. J. Life Cycle Assess. 2013, 18, 1116-1128. [CrossRef]

45. Albrecht, S.; Brandstetter, P.; Beck, T.; Fullana-i-Palmer, P.; Grönman, K.; Baitz, M.; Deimling, S.; Sandilands, J.; Fischer, M. An extended life cycle analysis of packaging systems for fruit and vegetable transport in Europe. Int. J. Life Cycle Assess. 2013, 18, 1549-1567. [CrossRef]

46. PROSUITE. Handbook on a Novel Methodology for the Sustainability Impact Assessment of New Technologies. 2013. Available online: www.prosuite.org (accessed on 4 September 2017).

47. Valente, C.; Saur Modahl, I.; Askham, C. Method Development for Life Cycle Sustainability Assessment (LCSA) of New Norwegian Biorefinery. Project Title: Nytt Norsk Bioraffineri, Report No.: OR.39.13. 2013, p. 62. Available online: https://www.ostfoldforskning.no/media/1141/3913.pdf (accessed on 8 January 2018).

48. Weidema, B. The integration of economic and social aspects in life cycle impact assessment. Int. J. Life Cycle Assess. 2006, 11, 89-96. [CrossRef]

49. De Luca, A.I.; Iofrida, N.; Strano, A.; Falcone, G.; Gulisano, G. Social life cycle assessment and participatory approaches: A methodological proposal applied to citrus farming in Southern Italy. Integr. Environ. Assess. Manag. 2015, 11, 383-396. [CrossRef] [PubMed]

50. Siebert, A.; Bezama, A.; O'Keeffe, S.; Thrän, D. Social life cycle assessment: In pursuit of a framework for assessing wood-based products from bioeconomy regions in Germany. Int. J. Life Cycle Assess. 2018, 23, 651-662. [CrossRef]

51. Dreyer, L.; Hauschild, M.; Schierbeck, J. A framework for social life cycle impact assessment. Int. J. Life Cycle Assess. 2006, 11, 88-97. [CrossRef]

52. Mattila, T.J.; Judl, J.; Macombe, C.; Leskinen, P. Evaluating social sustainability of bioeconomy value chains through integrated use of local and global methods. Biomass Bioenergy 2018, 109, 276-283. [CrossRef]

53. Benoit-Norris, C.; Cavan, D.A.; Norris, G. Identifying social impacts in product supply chains: Overview and application of the social hotspot database. Sustainability 2012, 4, 1946-1965. [CrossRef]

54. UNEP-SETAC. Guidelines for Social Life Cycle Assessment of Products; United Nations Environment Programme: Paris, France, 2009.

55. UNEP SETAC. The Methodological Sheets for Subcategories in Social Life Cycle Assessment (S-LCA) Pre-Publication Version. 2013. Available online: http:/ / www.lifecycleinitiative.org/wp-content/uploads / 2013/11/S-LCA_methodological_sheets_11.11.13.pdf (accessed on 3 July 2017).

56. De Haes, H.U.; Finnveden, G.; Goedkoop, M.; Hauschild, M.; Hertwich, E.G.; Hofstetter, P.; Jolliet, O.; Klöpffer, W.; Krewitt, W.; Lindeijer, E.; et al. Life-Cycle Impact Assessment: Striving Towards Best Practice; Society of Environmental Toxicology and Chemistry (SETAC): Pensacola, FL, USA, 2002.

57. Schaubroeck, T.; Rugani, B. A revision of what life cycle sustainability assessment should entail: Towards modeling the Net Impact on Human Well-Being. J. Ind. Ecol. 2017, 21, 1464-1477. [CrossRef]

58. Sherwood, J.; Clark, J.H.; Farmer, T.J.; Herrero-Davila, L.; Moity, L. Recirculation: A New Concept to Drive Innovation in Sustainable Product Design for Bio-Based Products. Molecules 2016, 22, 48. [CrossRef] [PubMed]

59. Sala, S.; Vasta, A.; Mancini, L.; Dewulf, J.; Rosenbaum, E. Social Life Cycle Assessment-State of the Art and Challenges for Supporting Product Policies; Publications Office of the European Union: Luxemburg, 2015.

60. Falcone, P.M.; Lopolito, A.; Sica, E. The networking dynamics of the Italian biofuel industry in time of crisis: Finding an effective instrument mix for fostering a sustainable energy transition. Energy Policy 2018, 112, 334-348. [CrossRef]

61. Hagemann, N.; Gawel, E.; Purkus, A.; Pannicke, N.; Hauck, J. Possible futures towards a wood-based bioeconomy: A scenario analysis for Germany. Sustainability 2016, 8, 98. [CrossRef]

62. Sijtsema, S.J.; Onwezen, M.C.; Reinders, M.J.; Dagevos, H.; Partanen, A.; Meeusen, M. Consumer perception of bio-based products-An exploratory study in 5 European countries. NJAS-Wagening. J. Life Sci. 2016, 77, 61-69. [CrossRef] 
63. Vandermeulen, V.; Van der Steen, M.; Stevens, C.V.; Van Huylenbroeck, G. Industry expectations regarding the transition toward a biobased economy. Biofuels Bioprod. Biorefin. 2012, 6, 453-464. [CrossRef]

64. McCormick, K.; Kautto, N. The bioeconomy in Europe: An overview. Sustainability 2013, 5, $2589-2608$. [CrossRef]

65. Koenig-Lewis, N.; Palmer, A.; Dermody, J.; Urbye, V. Consumers' evaluations of ecological packaging-Rational and emotional approaches J. Environ. Psychol. 2014, 37, 94-105. [CrossRef]

66. Elghali, L.; Clift, R.; Sinclair, P.; Panoutsou, C.; Bauen, A. Developing a sustainability framework for the assessment of bioenergy systems. Energy Policy 2007, 35, 6075-6083. [CrossRef]

2018 by the authors. Licensee MDPI, Basel, Switzerland. This article is an open access article distributed under the terms and conditions of the Creative Commons Attribution (CC BY) license (http://creativecommons.org/licenses/by/4.0/). 